\title{
Sustainability of Cultural Heritage Tourism: A Study Based on Cultural Triangle in Sri Lanka
}

\author{
Wijesooriya, M.W.A.T.N
}

Sri Lanka Institute of Advanced Technological Education

nirmanie@sliate.ac.lk

\begin{abstract}
Cultural heritage tourism is one of the fastest-growing forms of tourism. The cultural triangle in Sri Lanka has great potentiality to develop cultural heritage tourism as it consists of unique cultural and heritage attractions including five of the UNESCO world heritage sites. Enhancing Sustainability is the key factor for developing the cultural triangle as one of the sustainable cultural heritage tourism destinations. Through the research, focus to identify how to achieve sustainable cultural heritage tourism in the cultural triangle. The main objective of the study is to achieve destination sustainability and identifying the potentiality for cultural heritage tourism development in the cultural triangle. The research is conducted using the quantitative method and primary data use to test the four hypotheses and to identify the correlation. A structured questioner was given to the non-randomly selected $265(N)$ international tourists to represent their perceptions. SPSS was used to analyze the data. The results reveal that the most visited attractions in the cultural triangle and the four hypotheses were accepted. As the major findings identified that stakeholder involvement, economic development, environmental conservation, tourist satisfaction are leads to achieve sustainable cultural heritage tourism development in the cultural triangle, Sri Lanka.
\end{abstract}

Keywords: culture, heritage, tourism, cultural triangle, sustainability 


\section{Introduction}

Cultural heritage tourism has become one of the significant sectors of the tourism industry today. Cultural and Heritage Tourism is a tool of economic development that achieves economic growth through attracting visitors from outside a host community, who are motivated wholly or in part by interest in the historical, artistic, scientific or lifestyle/heritage offerings of a community, region, group or institution (Silberberg .,1995). Cultural and heritage tourists stay longer and spend more money than other kinds of travellers thus making such tourism an important economic development tool (ACHP.,2002). Cultural tourists tend to be motivated by 'learning something new', 'hoping to enrich their lives through their travel experience's and 'education and enrichment'(Walker.,2005). As a cultural heritage tourism destination in Sri Lanka, the cultural triangle representing a tremendous cultural and heritage value and the destination provides unique tourism products within a tangible and intangible way. According to the central cultural fund financial reports 2017, there was 994,556 tourist admission tickets sold by the cultural fund. Cultural Triangle consists of the Buddhist Temples, Sculptures, Ancient Monasteries and Stupas while some of them date back to over 2000 years. Also, UNESCO world heritage attractions such as the Sacred City of Anuradhapura, the Ancient city of Polonnaruwa, the Ancient city of Sigiriya, the Ancient City of Dambulla and the Sacred City of Kandy situated in the cultural triangle. According to the Sri Lanka Tourism Development Authority (SLTDA) Annual Statistical Report 2019, the purpose of the visit to Sri Lanka for cultural and religious factors was identified as $0.03 \%$ by the international tourists. There were 730,854 international tourists reported to the cultural triangle and $3,288,153,475.22$ (Rs) revenue generated in 2019. Also, there were 1,021,881 domestic tourists visited for the cultural triangle and 40,561,880.00 (Rs) revenue generated in 2019 (SLTDA Annual statistical report 2019).

Sustainability is the major factor for the success of any tourism destination and the tourism industry. Sustainability has become almost universally accepted as a desirable and politically appropriate approach to tourism development 
(Sharpley,.2003). Therefore, to promote the cultural triangle as a cultural heritage tourism destination it should achieve sustainability.

\section{Research Problem}

Some researchers have identified the challenges to develop a cultural triangle as a sustainable tourism destination. Udurawana. (2015) stated that almost all the places of a cultural triangle have no enough consideration to retain their tourist than other places. According to the destination Kandy, Sivesan. (2019) stated that lacking infrastructure, lacking community participation, lacking tourists' facilities are the major challenges to sustainable tourism development in Kandy. Also, Udurawana. (2014) stated that tourists' awareness about scared places at the Anuradhapura area was very poor level. Cultural Triangle has become one of the major cultural heritage tourism destinations in Sri Lanka which has the greatest potentiality to promote its tremendous value for the tourists. When developing cultural heritage tourism in the cultural triangle it should promote according to sustainable principles. Muller. (1994) stated that economic wellbeing, the wellbeing of locals, undisturbed nature and protection of resources, a healthy culture, optimum guest satisfaction affects sustainable tourism development. If the tourism destination cannot achieve sustainability it can be affected negatively for the industry such as it will get more negative impacts through the environmental, socio-cultural and economic sectors and it will cause the destruction of the destination. Tourists will not be able to get a satisfied or fruitful experience. Therefore, achieving sustainability is a vital factor for a destination when it promoting for the tourism industry. According to the study, the researcher expects to identify the question "How to achieve the sustainability of the cultural heritage tourism in the cultural triangle?". The researcher focuses to identify the factors which can affect sustainable cultural heritage tourism and approach them in a relevant way to enhance the destination development.

\section{Research Objectives}

The main objectives of this research are,

- To enhance the sustainability in the cultural triangle. 
- Identify the major cultural heritage attractions in the cultural triangle.

- Identify the target visitor market for the cultural triangle.

- Identify the purpose of visits of the international tourists to the cultural triangle.

\section{Significance of the study}

There are different types of stakeholders benefiting from this research. International tourists, local community, resource administrators such as government, Tourist Board, Hotel school, The Central Cultural Fund, Urban Development Authority and also the tourism entrepreneurs such as small-medium entrepreneurs can benefit through this research for developing their products.

\section{Methodology}

The research is conducting to identify how to develop sustainable cultural heritage tourism in the cultural triangle and applying sustainable principles. The researcher has used primary and secondary data. The primary data were compiled by a questionnaire to evaluate the factors for the international tourists to decide to select a cultural triangle as a cultural heritage tourism destination and the possibility of achieving the sustainability of the destination. Secondary data was collected from publications, internet sources, annual statistical reports produced by Sri Lanka Tourism Development Authority in 2018 and 2019, Tourism strategic plan 20172020-Ministry of Tourism Development and Christian Religious Affairs.

\section{Conceptual framework}

For creating the conceptual framework previous literature review has been used by the researcher. According to the study purpose the conceptual framework is designed for achieving sustainable cultural heritage tourism development in the cultural triangle, Sri Lanka. 
Independent Variables

Dependent Variable

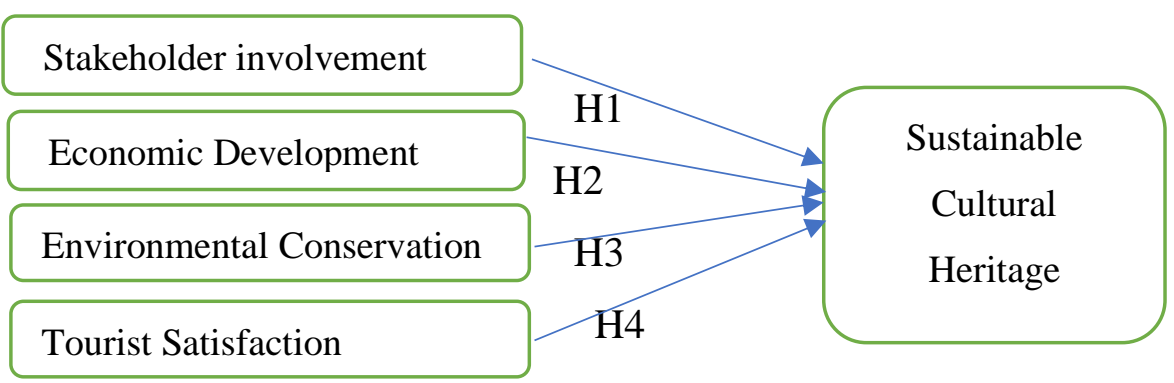

Figure1: Conceptual framework for Sustainable cultural heritage tourism Development in the cultural triangle, Sri Lanka

Wilson, J., (2010) stated that a deductive approach is concerned with developing a hypothesis based on existing theory, and then designing a research strategy to test the hypothesis. For this research deductive research approach has been used to test the hypothesis. According to the conceptual framework, the researcher developed four hypotheses.

- H1: Stakeholder Involvement leads to achieving the sustainable cultural heritage tourism

- H2: Economic Development leads to achieving the sustainable cultural heritage tourism

- H3: Environmental Conservation leads to achieving the sustainable cultural heritage tourism

- H4: Tourist Satisfaction leads to achieving the sustainable cultural heritage tourism

International tourists who visited the cultural triangle were selected as the target population of the research. Annual statistical reports of SLTDA stated that there were 730,854 tourists' arrivals reported to the cultural triangle in 2019. Therefore, the limitation of the sample size for the study was selected as 265 international tourists. Infinite random sampling method has been used to collect the data. The research 
instrument is the structured questionnaire. The research questionnaire was developed and administered to explore both the demand-side and supply-side for identifying the potentiality of cultural heritage tourism development in the Cultural triangle. When creating the questionnaire Nominal and 5-point Likert scales were used. The nominal scale shows the demographic profile of respondents while the Likert scale measures the respondents' preference according to each factor. The data was collected from $01^{\text {st }}$ June to $20^{\text {th }}$ September 2019. As target respondents, international tourists who visit the attractions in a cultural triangle such as Sacred city of Kandy, Sacred city of Anuradhapura, Ancient city of Polonnaruwa, Dambulla Cave Temple and Sigiriya Rock were selected. The researcher used the SPSS to analyse the data collected through the questionnaire. The data was gathered from the questionnaire and to analyze the data, it was entered into SPSS statistic version 23.

\section{Result and Discussion}

According to the findings it has proved that the majority of the international tourists visited the cultural triangle for cultural purposes. Most of the international tourists reported from Asia and Pacific, Europe and North America respectively. According to the respondent's data, the researcher has identified the most visited attractions in the cultural triangle. Sacred Tooth Relic 98\%, Lankathilaka temple 63\%, Gadaladeniya 61\%, Gal viharaya 91\%, Sigiriya Rock 96\%, Ruwanveli Mahaseya 95\%, Sri Maha Bodi 95\%, Abayagiriya 89\%, Dambulla cave Temple 86\% reported as the major visiting attractions by the international tourists. Also, to test the fourhypotheses researcher facilitated the Pearson's correlation analysis.

\begin{tabular}{|c|c|c|c|c|}
\hline & Independent Variable & $\begin{array}{l}\text { Correlation } \\
\text { Coefficient }\end{array}$ & $\mathrm{N}$ & $\begin{array}{l}\text { Sig. (2- } \\
\text { tailed) }\end{array}$ \\
\hline \multirow{4}{*}{ Pearson } & Stakeholder Involvement & $.289 * *$ & 265 & .001 \\
\hline & Economic Development & $.258 * *$ & 265 & .004 \\
\hline & Environmental Conservation & $.289 * *$ & 265 & .001 \\
\hline & Tourist Satisfaction & $.258 * *$ & 265 & .004 \\
\hline
\end{tabular}


**. Correlation is significant at the 0.01 level (2-tailed).

Table 1- Correlation between dependent and independent variables Source: Self-survey

According to the results, it can identify stakeholder involvement, economic development, environmental conservation and tourist satisfaction are significant to increase the sustainable cultural heritage tourism, being positively correlated. Therefore, the four hypotheses are accepted.

\section{Conclusion}

The study was set out to identify the "How to achieve the sustainability of the cultural heritage tourism in the cultural triangle?'. The research limitation to the cultural triangle and target respond group is the international tourists who visit the destination. The researcher achieved all research objectives through testing the four hypotheses. The researcher identified sustainable cultural heritage tourism in the cultural triangle can achieve through enhancing the stakeholder involvement to develop cultural heritage tourism, increasing economic development, more consideration on environmental conservation and increasing tourist satisfaction.

\section{Recommendations}

To increase the stakeholder involvement in the cultural triangle, tourist involvement, community involvement, tourism entrepreneurs, tourism administrators should be cooperated when planning the cultural heritage tourism. The local community can work as site guides, interpreters within the destination. It will be beneficial for the tourists to get authentic knowledge of the destination. Community empowerment can achieve through developing the small medium-sized tourism enterprises (SME) relating to the destination such as mats, cane, Ayurveda products, brassware, batik, pottery and handicrafts. Also, it will cause the economic development of the country. Authorities should obtain government assistantships and sponsorships also can establish training centres for the local community to promote their products. The community can increase the revenue through organizing the tradeshows, advertising campaigns and exhibitions for their products. Tourism entrepreneurs should market their products at a quality and affordable price. 
Product diversification affects greatly developing the cultural heritage tourism in the cultural triangle and it causes to increase in the level of tourist satisfaction. New tourism products can be market within cultural heritage tourism such as cycle tours within the cultural triangle attractions, cultural events and festivals, boat tours in Anuradhapura and Polonnaruwa lakes, developing and promoting rural and community-based tourism in Anuradhapura and Polonnaruwa. Environmental sustainability leadership programs and awareness programs can conduct for the students of the schools in the cultural triangle to be aware of the value of protecting the environment. Authorities should create new conservation projects to conserve the environment and the heritage in the destination.

Authorities can build up image development projects with the collaboration of the stakeholders for the cultural triangle. The assistantships of SLTDA and SLTPB can create documentary competition for lesser-known attractions in the cultural triangle. Authorities can give a chance to promote the awarded documentaries for marketing the Sri Lankan cultural heritage. Except for the main cultural and heritage attractions, there are so many lesser-known attractions in the cultural triangle such as Kuttam Pokuna, Ethpokuna, Asokarama, Pratimaghara in Jeetavanarama Moonstones No 01 and 02 in Abayagiriya, Naipena Vihara in Polonnaruwa, Pabalu Vehera, Pidurangala, World Buddhist museum, Kaludiya pokuna and these attractions can use to develop the cultural heritage tourism in Sri Lanka. Therefore, the authorities can promote these attractions using relevant advertising and promotion methods such as magazines and websites. It will cause to increase the motivation of international and domestic cultural heritage tourists to visit the cultural triangle. The above recommendations can be used to promote the cultural triangle as a sustainable cultural and heritage tourism destination in Sri Lanka. Achieving the above sustainable principles leads to conserve the destination and leads to protect it for the future generation. 


\section{References}

Abuamoud, I. N., Libbin, J., Green, J., \& ALRousan, R. (2014). Factors affecting the willingness of tourists to visit cultural heritage sites in Jordan. Journal of Heritage Tourism, 9(2), 148-165.

Banerjee, O., Henseler, M., Maisonnave, H., Beyene, L. M., \& Velasco, M. (2017). An integrated model for evaluating investments in cultural heritage tourism in the Dominican Republic. Tourism Economics, 23(8), 1568-1580.

Berry, S., \& Ladkin, A. (1997). Sustainable tourism: a regional perspective. Tourism Management, 18(7), 433-440.

Boyd, S. (2002). Cultural and Heritage Tourism in Canada: Opportunities, Principles and Challenges. Tourism and Hospitality Research, 3(3), 211-233.

Cleere, H. (Ed.). (1990). Archaeological Heritage Management in the Modern World (1st ed.). Routledge

Grimwade, G., \& Carter, B. (2000). Managing Small Heritage Sites with Interpretation and Community Involvement. International Journal of Heritage Studies, 6(1), 33-48.

Jiménez-Medina, P., Artal-Tur, A., \& Sánchez-Casado, N. (2020). Tourism Business, Place Identity, Sustainable Development, and Urban Resilience: A Focus on the Sociocultural Dimension. International Regional Science Review, 44(1), 170-199.

Mckercher, B., \& Cros, D. H. (2002). Cultural Tourism: The Partnership Between Tourism and Cultural Heritage Management (1st ed.). Routledge 